91(477):631.4

\author{
1961-2011 \\ • ельник, . $\mathbf{y x}$ \\ ьвівський н ціон льний університет імені в н \\ вул. . орошенк , 41, м. ввів, 79000, кр їн
}

укові дослідження н к федрі фізичної геогр фії, одній з н йст ріших к федр геогр фічного ф культету ьвівського університету, в ост нні півстоліття були пов'яз ні головно з комплексним фізико-геогр фічним вивченням з хідної ч стини кр їни, розробкою теоретичних, методичних і прикл дних пит нь л ндш фтозн вств . підсумку сформув л сь львівськ школ л ндш фтозн вств проф. . еренчук т школ гірського л ндш фтозн вств проф. . іллер . укові розробки співробітників к федри грунтуються не лише н експедиційних, й н ст ціон рних дослідженнях, які впродовж б г тьох років безперервно проводять н озтоцькому л ндш фтно-геофізичному (з 1968 р.) т орногірському геогр фічному (з 1978 р.) ст ціон $\mathrm{p}$ х.

лючові слов : к федр фізичної геогр фії, н укові дослідження, ст ціон рні дослідження, л ндш фтозн вство.

сновними н прям ми н укової роботи однієї з н йст ріших к федр геогр фічного ф культету к федри фізичної геогр фії (створен у вересні 1944 р.) були геоморфологічні ( . еренчук), клім тичні ( . ндрі нов) т з г льні фізико-геогр фічні ( . рел, . ойнов, . ільбер) дослідження, які ще з 1787 р. $з$ поч ткув в у ьвівському університеті встрійський професор природозн вств . кет, 31883 р. продовжили н к федрі геогр фії університету польські вчені . ем н, . омер, . ибовский т укp їнські вчені . удницький i . олянський. е ст ло підгрунтям розгорт ння н поч тку 60-х років н к федрі грунтозн вчих і комплексних л ндш фтозн вчих досліджень т формув ння відповідних експедиційних колективів, н укових шкіл.

1954 по 1974 рр. к федрою фізичної геогр фії з відув в . еренчук (1904-1984рp.) - доктор геогр фічних н ук з 1958 р., професор з 1960 р., фізико-геогр ф широкого профілю, н укові інтереси якого пов'яз ні з геоморфологією, л ндш фтозн вством, охороною природи т історією природничої геогр фії. ід його керівництвом з хищено 10 к ндид тських дисерт цій з л ндш фтної тем тики, зокрем , з вивчення л ндш фтів олинського олісся ( . рел (1955) т . лимович 1963)), орногори ( . іллер (1963), м. ернівці ( . орфм н (1966), трийсько- янської верховини ( . рохимчук (1968), р вш нського хребт і прилеглих рівнин ( . лібеков (1968), б сейну р. нз р м рк ндської обл. ( . жум б єв (1968), янсько- ністерського межиріччя ( . денюк (1973), розробки геогр фічних основ земельного к д стру гірських регіонів ( . опчієв (1966), вивчення сезонної дин міки л ндш фтів ьвівщини ( . роць (1967) т мікроклім тичних х р ктеристик природних територі льних комплексів одр ( . ошкод н (1971). к сформув л сь львівськ школ л ндш фтозн вств проф. . еренчук (рис. 1).

(C) ельник ., ух ., 2012 


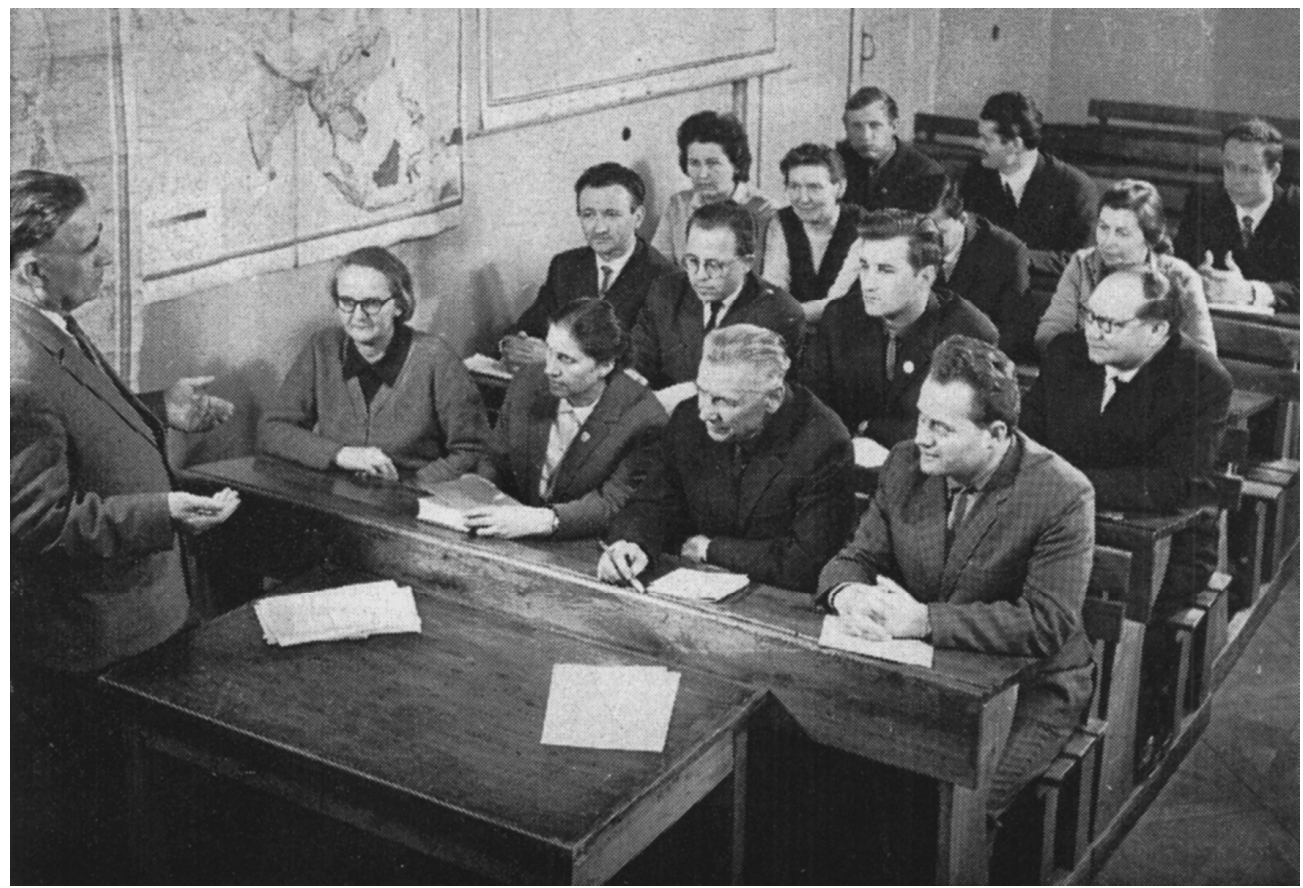

ис. 1. сід ння к федри фізичної геогр фії проводить з відув ч, проф. • еренчук: спр в н ліво перший ряд: . ретяк, . ндрі нов, . устовєтов ; другий ряд: . ойнов, . остюченко, . цюк, . іллер; третій ряд: . оролько, . у ух , . роць, . ерев'янко; четвертий ряд: . опчієв, . рохимчук, . іт. ото . рмоленк , 1965.

ктивн н уков робот к федри під ч с керівництв . еренчук виявил сь не лише в н пис нні й з хисті дисерт цій, формув нні розвитку львівської школи л ндш фтозн вств, й у функціонув нні двох грунтозн вчих експедицій з л бор торією н лізу грунтів, н уково-дослідної л бор торії якісної оцінки земель т комплексної експедиції з вивчення шкідливих стихійних процесів у рп т х, н пис нні моногр фій.

ри к федрі фізичної геогр фії т ьвівському відділі геогр фічного тов риств 1957-1967 pр. функціонув л створен . оголєвим експедиція для обстеження і к ртогр фув ння грунтів т л бор торія н лізу грунтів. . оголєв у 1965 р. з хистив докторську дисерт цію н тему “ урі гірсько-лісові грунти дянських рп т”, з поч ткув в львівську грунтозн вчу школу.

1961 по 2000 pр. у н уково-дослідному секторі ьвівського університету діял ще одн грунтозн вч експедиція, як переросл в потужну н уково-дослідну л бор торію ( -50). 1970-80-ті роки її шт т н лічув в близько 90 осіб. г торічним керівником (1968-1999) був . іт. уковою тем тикою керув ли професори і доценти к федри фізичної геогр фії. бор торія проводил великом сшт бне обстеження грунтів, грунтово-ерозійні і грунтово-меліор тивні дослідження в різних регіон х кр їни, осії і 3 хст ну.

1961-1965 рр. при к федрі функціонув л н уково-дослідн л бор торія якісної оцінки земель (з відув ч . цюк), дослідження якої грунтув лись н використ нні 
л ндш фтно-геохімічних методів. езульт том досліджень л бор торії ст л колективн моногр фія “ снови методики земельного к д стру гірських р йонів” (1966), теоретико-методичні розробки використ ні в держ вних інструкціях 3 к ртогр фув ння типів земель т їхньої якісної оцінки.

дноч сно з двом грунтозн вчими експедиціями т л бор торією якісної оцінки земель у 1965-1970 рр. пр цюв л ще одн експедиція - комплексн експедиція з вивчення шкідливих стихійних процесів у рп т х, у скл ді якої діяв л ндш фтний з гін (керівник . іллер). езульт т ми роботи експедиції ст ли серія цільових л ндш фтних к рт м сшт бу 1:100 000, н ліз зв'язку х р ктеру т інтенсивності прояву шкідливих стихійних явищ з л ндш фтною структурою території, т кож розроблено рекоменд ції щодо з побіг ння т ліквід ції н слідків стихійних процесів у природних територі льних комплекс х і з г льні положення для ведення лісового господ рств 3 ур хув нням л ндш фтної структури гірських територій.

н чним досягненням колективу к федри у 1960-70-х рок х ст ло вид ння низки пр ць, присвячених природі рідного кр ю. ершою моногр фією цього пл ну бул пр ця . ойнов “ " рирод т нісл вської обл сті” (1960). 1964 р. вийшл пр ця . еренчук , . ися i . ойнов “ риродно-геогр фічний поділ ьвівського т одільського економічних р йонів”, 1968 р. - колективн моногр фія “ рирод кр їнських рп т” з ред кцією . еренчук . продовж 1972-1982 рр. 3 ред кцією . еренчук опубліков но серію моногр фій “ рирод ...” для кожної з восьми дміністр тивних обл стей з ходу кр їни.

шістдесяті роки . еренчук ктивно просув в ідею вивчення кількісних пок зників л ндш фтів різними метод ми (експедиційними, к ртометричними), проте н йперспективнішим ув ж ли метод дослідження функціонув ння природних територільних комплексів н геогр фічних ст ціон $\mathrm{p}$ х.

огляду н це т з метою ефективного проведення пр ктик у 1959 р. створено геогр фічний ст ціон р у с. зупіль исменецького р-ну в но- $\mathrm{p}$ нківської обл. т метеорологічну обсерв торію при к федрі. 1968 р. обсерв торію перетворено н озтоцький л ндш фтно-геофізичний ст ціон р у смт рюховичі (орг ніз тор і н уковий керівник ст ціон ру з 1968 р. по д ний ч с доц. . ух ). ізніше розгорнулись н уководослідні роботи к федри н цькому біолого-геогр фічному ст ціон рі, зокрем , лімнологічні т б тиметричні (ст ціон р створений 1971 р. біля смт цьк, юбомльського р-ну, олинської обл.).

ротягом 1974-1994 рр. к федрою фізичної геогр фії керув в . . іллер (рис. 2), учень . еренчук , доктор геогр фічних н ук, професор, у 1976-1984 рр. дек н геогр фічного ф культету. ільшість н укових пр ць він присвятив проблем м л ндш фтозн вств гірських і передгірських територій; розробив методику експедиційного дослідження гірських л ндш фтів, обгрунтув в концепції про структурну ієр рхію т пульс ційний розвиток, вік і умови ст біліз ції гірських л ндш фтів.

к федрі ктивно розширюв л ся сфер н укових пошуків у л ндш фтозн встві: у 1979 р. к ндид тську дисерт цію н тему “ еоретичні і методичні проблеми середньом сшт бних л ндш фтних досліджень” з хистив . укурудз у 1980 р. хистив докторську дисерт цію н тему “" ндш фтні дослідження гірських територій” . іллер, к ндид тську “ еоретичні основи і методичні способи л ндш фтних досліджень для осушув льних меліор цій” - . ух .

80-х рок х к федр фізичної геогр фії під керівництвом . іллер виконув л н укові теми республік нського координ ційного пл ну: “ ндш фтне обгрунтув ння 
природоохоронних з ходів у приміській зоні міст ьвов ” (1979-1981), “ еогр фічні основи р ціон льного природокористув ння в ( тин олісся” (1981-1986 рр.), “ ндш фтні дослідження кр їни з метою р ціон льного природокористув ння ( кр їнські рп ти, олино- оділля, з хідн ч стин олісся” (1986-1990), “ снови оптиміз ції природокористув ння в територі льних систем х 3 хідного регіону кр їни (функціонув ння, моніторинг, експертиз , прогноз” (1990-1993) т госпдоговірного х р ктеру: “ ндш фтне обгрунтув ння природоохоронних з ходів під ч с будівництв м гістр льних трубопроводів” (1983-1984 рр., керівник . іллер), “ ивчення л ндш фтно-геофізичних х р ктеристик у з хідному регіоні кр їни щодо з д ч дешифрув ння дист нційних д них, т кож м тем тичного моделюв ння вологопереносу в верхніх горизонт х грунтів” (1983-1986 рр., керівник . регіон льного екологічного моніторингу” (1991-1992 рр., керівник . іллер).

р мк х рп то- олино- одільської експедиції геогр фічного ф культету в 1985-1990 pр. пр цюв л очолюв н . іллером р нск рп тськ л ндш фтн експедиція, як провел унік льне експедиційне обстеження рп т по профілях олин ячів т оловець- жгород. експедиції пройшл вишкіл більшість нинішніх викл д чів к федри фізичної геогр фії - . етлін, . ельник, . едірко, . руглов, . гульськ, . убер, т кож. йц р (к федр геогр фії кр їни) т . иротюк (к федр $\mathrm{p}$ ціон льного використ ння природних ресурсів і охорони природи).

озтоцькому л ндш фтно-геофізичному ст ціон рі продовжув ли метеорологічні, ктинометричні і гр дієнтні спостереження ( . у ух ), н цькому - мікроклім тичні т гідрологічні дослідження природних територі льних і кв льних комплексів ( . роць- р вчук). 1978 р. . іллер 3 снув в орногірський геогр фічний ст ціон р у верхів'ї р. рут (з 14 км від смт орохт в но- р нківської обл.), де розгорнулись дослідження функціонув ння гірських ф цій ( . едірко, · етлін). укове керівництво ст ціон ром пров див . іллером (до 1994 р.), 31994 р. - . ельником.

ід керівництвом проф. . іллер розробляли нові н прями л ндш фтозн вств і з хищ ли дисерт ції, що стосуються л ндш фтного вивчення лісоп тологій ( . едірко, 1988 р.), дин міки л ндш фтних ф цій орногори ( . етлін, 1988 р.), моніторингу природних територі льних комплексів ( . ельник, 1991 р.), урб нізов них територій (. руглов, 1992 р.) - формув л ся львівськ школ гірського л ндш фтозн вств проф. . іллер .

еред н укових публік цій моногр фічного х р ктеру н звемо “ ндш фтные исследов ния горных и предгорных территорий” ( . іллер, 1974) т “ ндш фтний моніторинг” ( . ельник, . іллер, 1993).

ровідні позиції к федри фізичної геогр фії в г лузі л ндш фтозн вств вдруге підтвердженні н VIII сесоюзній н р ді з пит нь л ндш фтозн вств, проведеній н 6 зі к федри 1988 р. (у 1956 р. проведено ругу всесоюзну н р ду з л ндш фтозн встB ).

уже цік вою і своєрідною формою н укової роботи студентів к федри у 90-х рок х ст ли щорічні (відбув лись упродовж десяти років) міжвузівські студентські н укові експедиції з дослідження зимових ст нів гірських л ндш фтних комплексів, фунд тор ми яких були ьвівський, біліський, осковський т енінгр дський ( нкт- етербурзький) університети (співробітник від ьвівського університету.$- \quad$ ух $).$ 


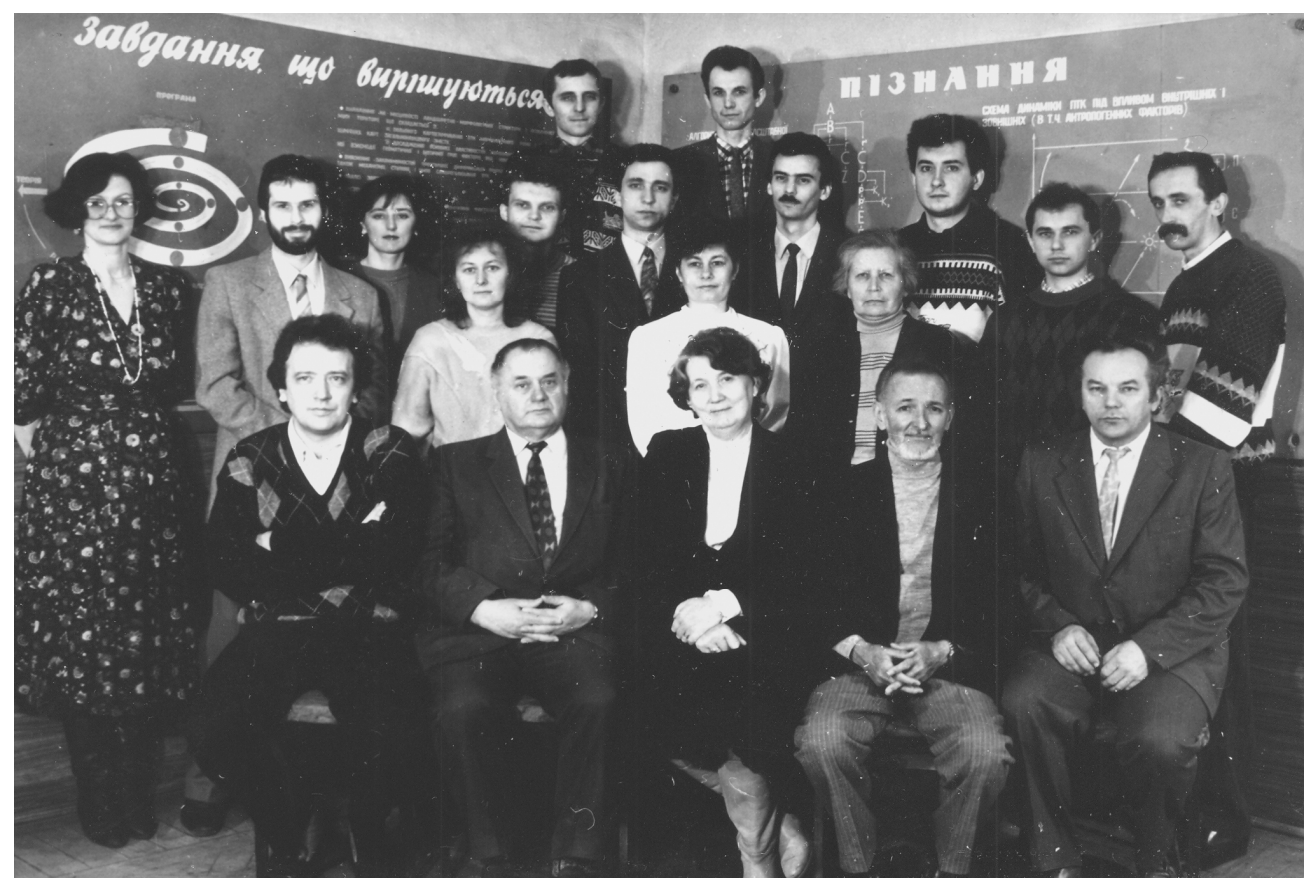

ис. 2. федр фізичної геогр фії (1992): злів н пр во перший ряд: . едірко, . ретяк, роць, . іллер, . ух ; другий ряд: . укурудз , . руглов, . м ль, . гульськ , . ерев'янко, твіїв, . л т; третій ряд: . ритул , . естерук, . іл нюк, . ороцянко, . ов льчук; четвертий ряд: . убер, . ельник. ото . ухи.

1994 до 2001 рр. роботою к федри фізичної геогр фії керув в . у ух - учень . еренчук т . лимович, к ндид т геогр фічних н ук, доцент. ого н укові інтереси пов’яз ні з дослідженням геофізичних процесів л ндш фтних комплексів.

90-х рок х ентузі сти к федри і ф культету виконув ли тему “ изн чення вітроенергетичного потенці лу природних територі льних комплексів кр їнських рп т” (керівник . ух ), “ ндш фтні основи т геоінформ ційне з безпечення оптиміз ції використ ння природних ресурсів (вітро-, водноенергетичних, земельних т ін.) 3 хідного регіону кр їни” (керівник . . у ух ); “ творення л ндш фтно-екологічної інформ ційної системи з хідного регіону кр їни” (керівник . ельник).

продовж чотирьох років (з 1983 по 1987 рр.) співробітники к федри виконув ли роботи з гідрометричного обстеження рік і ст вів ьвівської обл. 3 метою вибору місць для спорудження м лопотужних гідроелектрост нцій (керівник . ух ).

рив ло зрост ння кв ліфік ції молодих викл д чів, відбув ли з хисти к ндид тських дисерт цій - . укурудзи “ ндш фтно-геофізичний н ліз верхньогірсько-лісових л ндш фтів еликого вк зу” (1994 р., керівник . іллер), . у убер “ ндш фтн обумовленість диференці ції грунтового покриву кр їнських рп т” (1994р., керівник . іллер), . йц $\mathrm{p}$ “ ерхня меж лісу в л ндш фтних комплекс х кр їнських рп т” (1994р., керівник . іллер), . гульськ “ ндш фтн інтерпрет ція ерокосмічної інформ ції” (1995 р., керівник . іллер), . іл нюк “ плив тр с м гістр льних трубопроводів н гірськок рп тські л ндш фтні структури” (1999 р., ке- 
рівник . етлін), . твіїв “ ндш фтні основи оптиміз ції природокористув ння у кибових орг н х” (1999 р., керівник . едірко), т кож докторських дисерт цій . етлін “ кономірності орг ніз ції л ндш фтних ф цій” (1999 р.) т . ельник “ колого-л ндш фтозн вчий н ліз кр їнських рп т” (2001).

публіков но низку моногр фій, зокрем , . етлін “ кономірності орг ніз ції л ндш фтних ф цій” (1998), . іл нюк “ ндш фти кр їнських рп т в зон х тр с м гістр льних трубопроводів” (1998), . ельник “ снови регіон льного екологол ндш фтозн вчого н лізу” (1997) і “ кр їнські рп ти: еколого-л ндш фтозн вче дослідження" (1999).

в ліфік ційному зрост нню співробітників к федри у 90-ті роки сприяло н л годження співробітництв 3 х хідними держ в ми. кордоном проходили ст жув ння . руглов ( , встрія), . укурудз (, імеччин ), . ельник ( імеччин , встрія), . убер ( встрія), . ух ( осія, встрія, ольщ ).

2001 р. к федрою фізичної геогр фії з відує . ельник - учень . . іллер , доктор геогр фічних н ук, професор. ого н укові інтереси стосуються теорії, методики т прикл дних пит нь л ндш фтозн вств, геогр фічного моніторингу, екологічної геогр фії т геоекології. прикл ді кр їнських рп т теоретико-методичні основи л ндш фтного моніторингу т н укові основи регіон льного еколого-л ндш фтозН вчого н лізу гірських і передгірських територій.

2001-2003 рр. к федр бр л уч сть у викон нні держбюджетної теми “ еогр фічні проблеми хідного регіону кр їни” (керівник ст вний), у 2002-2004 підпроекту “ труктур л ндш фту т структур землекористув ння з д ними космозобр ження” (керівник . руглов) у р мк х німецько-укр їнського проекту “ р нсформ ційні процеси у б сейні ністр ”, у 2004-2006 - держбюджетної теми “ епресивні регіони кр їни” (керівник . ст вний), у 2007-2009 - держбюджетної теми “ ормув ння інформ ційного середовищ ст лого розвитку рп тського регіону кр їни" (керівники . ов льчук, . блій), з 2010 р. - держбюджетної теми “ кологічн , демокультурн , соці льно-економічн т геополітичн безпек регіону: геогр фічні проблеми н м тері л х к рп тських обл стей кр їни" (керівник . блій).

півробітники к федри під керівництвом · ельник виконув лись н укові теми в меж х робочого ч су: “ колого-л ндш фтозн вчий н ліз природних умов і природних ресурсів з хідного регіону кр їни” (2002-2004), “ еоекологічні проблеми з хідного регіону кр їни” (2005-2006), “ еоекологічний н ліз з хідного регіону кр їни для підтримки ст лого розвитку” (2007-2009) т “ ндш фтні передумови ст лого розвитку кр їнських рп т і олино- оділля” (2009-2011).

федр в ост ннє десятиліття тр диційно продовжув л готув ти спеці лістів вищої кв ліфік ції. окрем , у 2001 р. 3 хистив к ндид тську дисерт цію . в нов н тему “ колого-л ндш фтозн вчий н ліз гірничопромислових територій” (керівник . ельник), у 2006 р. кртчян - “ ндш фтно-екологічні основи інтегр ції д них в земельні інформ ційні системи” (керівник . руглов), у 2007 р. . ом нів “ ндш фтно-рекре ційний потенці л н ціон льного природного п рку “ иневир” (керівник . едірко), у 2010 р. . ворський - “ озвиток л ндш фтів кр їнського озточчя” (керівник . ух ), . остів - “ труктур , дин мік і оптиміз ція л ндш фтів ентр льного оділля” (керівник . ельник) i . ртинюк “" ндш фтно-лімнологічний н ліз олинського олісся в меж х івненської обл сті” (керівник . ух ).

ийшли в світ моногр фії . етлін “ инергетик л ндш фту” (2005) і “ тр тегія л ндш фту” (2007) т колективні моногр фії з уч стю співробітників к федри - “ ко- 
логічний н ліз регіону: експертн оцінк ст ну і функціонув ння" (2009, спів втори ельник, . ух ), “ оновий моніторинг н вколишнього природного середовищ ” (2010, спів втор . ельник) т ін.

ст нніми рок ми н новому суч сному рівні реорг нізов но інструмент льні ст ціон рні режимні дослідження процесів функціонув ння л ндш фтних комплексів озточчя й кр їнських рп т, які прогр мно проводять упродовж сорок років н озтоцькому л ндш фтно-геофізичному (н уковий керівник . у ух ) і впродовж тридцяти років н орногірському геогр фічному (н уковий керівник . ельник) ст ціон $\mathrm{p}$ х. цих ст ціон р х функціонують суч сні втом тичні метеорологічні ст нції, що 3 безпечує високу точність л ндш фтно-геофізичних спостережень, проводять л ндш фтнофенологічні, л ндш фтно-гідрологічні т інші дослідження, ведуть електронну б зу д них т комп'ютерне опр цюв ння результ тів.

ініці тиви к федри фізичної геогр фії проведено низку ф хових конференцій і семін рів, у тому числі й міжн родних, н яких обговорюв ли підсумки і перспективи л ндш фтозн вчих досліджень, зокрем : міжн родн н уков конференція “ ндш фтозн вство: тр диції і тенденції” ( ьвів, 2004), регіон льн н уково-пр ктичн конференція “ риродні комплекси і екосистеми верхів'я 6 сейну р. рут: функціонув ння, моніторинг, охорон " ( ьвів; орохт , 2009), міжн родний н уковий семін р “ т ціон рні геогр фічні дослідження: досвід, проблеми, перспективи” ( ьвів, 2010) т інші, 3 результ т ми яких опубліков но збірники н укових пр ць. ік вою формою н вч льно-н укової роботи ст ло проведення з ініці тиви к федри польових (зимової 2009 р. т літньої 2011 р.) шкіл гірського л ндш фтозн вств н 6 зі орногірського геогр фічного ст ціон ру.

ерспективними н прям ми н укових досліджень, н д якими сьогодні пр цюють н уковці к федри, є: теорія л ндш фтозн вств ; генезис, еволюція, структур , дин мік і суч сний ст н л ндш фтів; ст ціон рні дослідження процесів функціонув ння природних територі льних і кв льних комплексів; л ндш фтно-геофізичні т л ндш фтногеохімічні вл стивості природних територі льних комплексів т їхніх нтропогенних модифік цій; дист нційні методи л ндш фтозн вчих досліджень; з г льнон укове і прикл дне л ндш фтне к ртогр фув ння; з стосув ння геоінформ ційних технологій у л ндш фтозн вчих дослідженнях; л ндш фтн оцінк вітрових і водноенергетичних ресурсів; л ндш фтний моніторинг; л ндш фтозн вчий н ліз екологічних проблем; н укові основи р ціон льного природокористув ння і ст лого розвитку, збереження л ндш фтного різном ніття т охорон природи.

уковий потенці л к федри сьогодні - один доктор геогр фічних н ук, професор, сім доцентів, к ндид тів геогр фічних н ук, п'ять систентів (з них дв к ндид ти геогр фічних н ук), сім спір нтів і п'ять пошукув чів.

укові інтереси співробітників к федри (див. вкл. 2) стосуються теоретичних, методичних і прикл дних пит нь комплексних т г лузевих фізико-геогр фічних досліджень і пов'яз ні головно з л ндш фт ми хідного регіону кр їни, зокрем : проф. . ельник - дослідження структури і дин міки л ндш фтів кр їнських рп т, їхніх екологічних проблем, пит нь $\mathrm{p}$ ціон льного природокористув ння, моніторингу охорони; доц. . іл нюк - вивчення геогр фічних з кономірностей виникнення природних т нтропогенно спровоков них к т строф, т кож обгрунтув ння шляхів оптиміз ції ст нів геосистем, змінених к т строфічними процес ми, розробк н укових основ р ціон льного природокористув ння, ст лого розвитку т збереження л ндш фтного різном ніття; доц. . гульськ - розробк пит нь л ндш фтної інтерпрет ції 
ерокосмічної інформ ції т л ндш фтної індик ції н прикл ді л ндш фтних систем хідної кр їни, з стосув ння л ндш фтного підходу в кр єзн вчих, рекре ційних і туристичних дослідженнях; сист. . рпець - дослідження л ндш фтів олинської височини т обгрунтув ння з ходів щодо їхнього р ціон льного використ ння; доц. . руглов - дослідження л ндш фтів урб нізов них територій, геоекологічні дослідження в кр їнських рп т х, у б сейн х ерхнього ністр і хідного угу, розробк пит нь історії т методології геоекології; сист. . ул чковський - геоекологічний інформ ційний н ліз льпійських і лісових б сейнів хідних рп т; доц. . твіїв л ндш фтно-рекре ційні, л ндш фтно-туристичні т л ндш фтно-кр єзн вчі дослідження в кр їнських рп т х, розробк л ндш фтних з с д оптим льного природокористув ння; доц. . у ух - ст ціон рні т н півст ціон рні дослідження п р метрів функціону ння і топоклім т л ндш фтів пілля, озточчя, лого олісся, орногори; доц. . едірко - структур л ндш фтів і зонув ння природоохоронних територій, топонімічні дослідження; доц. . убер - дослідження грунтового покриву природних територі льних комплексів кр їнських рп т, клім ту л ндш фтів хідного регіону кр їни т його впливу н господ рську діяльність людини; доц. . ушняк - екзоморфодин мік гірських л ндш фтів, розробк н укових основ орг ніз ції природоохоронних територій т впров дження рп тської і ндш фтної європейських конвенцій; сист., к.г.н. остів - дослідження структури і дин міки л ндш фтів ентр льного оділля для їхньої оптиміз ції, процесів дин міки і функціонув ння природних територі льних комплексів орногори; сист., к.г.н. ворський - дослідження розвитку і структури л ндш фтів кр їнського озточчя; сист. . ритул - дослідження вітроенергетичного потенці лу природних територі льних комплексів кр їнських рп т; спір нт . ул венко - дослідження функціонув ння репрезент тивних геокомплексів убро-вицького л ндш фту івденного озточчя; спір нт . м н л ндш фтні з с ди орг ніз ції рекре ційно-туристичної діяльності в кр їнських рп т х; спір нт . овнер - л ндш фтно-екологічне обгрунтув ння оптиміз ції зелених зон урб нізов них територій; спір нт . м лійчук - дослідження суч сної нтропогенної дин міки л ндш фтів кр їнських рп т у меж х ьвівської обл.; спір нт . ок р - л ндш фто-зн вчий н ліз рекре ційно-туристичних ресурсів івненської обл.; спір нт . их нович - дослідження л винонебезпечних природних територі льних комплексів кр їнських рп т; спір нт . еремх - дослідження природного потенці лу л ндш фтів рибескидського ередк рп ття; . ерезяк - л ндш фтногідрологічний н ліз б сейну верхів'я р. рут у меж х рп т; . ілевич - розробк геогр фічних з с д ст лого розвитку гірських поселень (н прикл ді ьвівщини); их льчук - еколого-л ндш фтозн вчий н ліз лого олісся; . вк - л ндш фтний н ліз рекре ційних ресурсів кр їнського озточчя: ст н т перспективи використ ння; . уд - дослідження мікроклім ту геокомплексів івденного озточчя.

федр співпр цює і підтримує н укові зв'язки з ученими з провідних н вч льних 3 кл дів кр їни ( иївський, рківський, врійський, ернівецький, інницький т інші університети), ціон льної к демії н ук кр їни ( нститут геогр фії, нститут екології рп т т ін.), уст нов іністерств природи кр їни ( рп тський н ціон льний природний п рк, ворівський н ціон льний природний п рк т ін.) т 3 кордоном ( оскв, нкт- етербург, рш в, резден, р ц т ін.). 
1. федр фізичної геогр фії. о 60-річчя з снув ння к федри / з ред. . укурудзи - ьвів ид вничий центр імені в н р нк , 2004. - 164 с.

2. ельник . 60-років к федри фізичної геогр фії ьвівського н ціон льного університету імені в н р нк / . ельник, . ух , . еленч к // існ. ьвів. ун-ту. ер. геогр. - ип. 31. 2004. - .24-30.

3. $y x$. . федр фізичної геогр фії ьвівського н ціон льного університету. сторія т персон лії / . . ух .- ьвів : ид вничий центр імені в н р нк, 2004. - 430 с.

m ття: н дійшл до редколегії 06.12.2011 прийнят до друку 20.12.2011

\title{
THE MAIN RESEARCH TRENDS AT THE DEPARTMENT OF PHYSICAL GEOGRAPHY, IVAN FRAN O NATIONAL UNIVERSITY OF LVIV DURING 1961-2011
}

\author{
A. Melnyk, B. Mukha \\ Ivan Franko National University of Lviv, \\ . Doroshenko St., 41, UA - 79000 Lviv, Ukraine
}

The research at the Department, which is one of the oldest at the Geography Faculty of Lviv University (founded in 1944) has been mainly connected during the last half-century with integrated physical-geographical studies of Western Ukraine, development of theoretical, methodical, and applied issues of landscape science. As a result, the Lviv school of landscape studies of Prof. K.I. Herenchuk was formed, as well as the school of mountain landscape studies of Prof. H.P. Miller. The research activities of the Department staff are based not only on the expeditionary field data, but also on the data collected at the field stations - the Roztocha Landscape-Geophysical Station (functions since 1968) and the Chornohora Geographical Station (functions since 1978).

Key words: Department of Physical Geography, research activities, stationary observations, landscape science.

\section{1-2011}

\author{
• ельник, • $\mathbf{y x}$
}

ьвовский н ицон льный университет имени в н

ул. орошенко 41, г. ввов, 79000, кр ин

учные исследов ния н к федре физической геогр фии, одной из ст рейших к федр геогр фического ф культет ьвовского университет, в последние полвек были связ ны гл вным обр зом с комплексным физико-геогр фическим изучением з п дной ч сти кр ины, p зр боткой теоретических, методических и прикл дных вопросов л ндш фтоведения. итоге сформиров л сь львовск я школ л ндш фтоведения проф. . еренчук и школ горного л ндш фтоведения проф. . иллер . учные р зр ботки сотрудников к федры 6 зируются не только н экспедиционных, но и н ст цион рных исследов ниях, которые н протяжении многих лет беспрерывно проводятся н озтоцком л ндш фтно-геофизическом (с 1968 г.) и ерногорском геогр фическом (с 1978 г.) ст цион р х университет .

лючевые слов : к федр физической геогр фии, н учные исследов ния, ст цион рные исследов ния, л ндш фтоведение. 